\title{
Making Charcoal Water Electrodes
}

\author{
Amalia Amira Rashidah*, Amar Lohot Tanjung and Sindi H Sembiring \\ Department of Chemistry, Faculty of Mathematics and Natural Sciences, State University of Medan, \\ Jl. Willem Iskandar Pasar V Medan Estate, Medan 20221, Indonesia \\ *E-mail: amarttanjung@gmail.com
}

\begin{abstract}
Charcoal is the residual waste from the heat decomposition process of carbon-containing materials, most of whose components are carbon. This study aims to determine the frequency of charcoal water as an electrolyte solution to produce an alternative energy source that is environmentally friendly. The method used in the experiment is to find the type of water with the addition of zinc and copper and to measure the sample voltage of charcoal water to determine the optimum mass and optimum interaction time. The variation in the volume of water with $50 \mathrm{ml}$ and $100 \mathrm{ml}$ of charcoal water was produced, with the addition of zinc and copper in the size of $1 \times 5 \mathrm{~cm}, 2 \times 5 \mathrm{~cm}, 3 \times 5 \mathrm{~cm}$ which resulted in fluctuations in each data. For example, the difference in voltage value in the type of water used is tap water, $100 \mathrm{ml}$ well water with the addition of zinc and copper measuring $2 \times 5 \mathrm{~cm}$. Tap water, namely with an electric voltage of $0.65 \mathrm{~V}, 0.70 \mathrm{~V}, 0.60 \mathrm{~V}, 0.60 \mathrm{~V}, 0.75 \mathrm{~V}$ and well water with an electric voltage of $0.60 \mathrm{~V}, 0.55 \mathrm{~V}, 0.55 \mathrm{~V}, 0.55 \mathrm{~V}, 0.55 \mathrm{~V}$. Less than the maximum frequency produced with two glasses that are not made into a series or parallel circuit.
\end{abstract}

Keywords: Charcoal water, carbon, electrodes.

\section{Pendahuluan}

Kehidupan manusia tidak terlepas dari penggunaan listrik, seperti mencuci baju, menonton televisi, belajar, menyalakan AC, menyalakan lampu dan sebagainya. Tidak ada seharipun kita tidak menggunakan energi listrik. Pasti saat mati lampu kita akan merasakan betapa ketergantungan kita kepada energi listrik. Misalnya, pada malam hari PLN mengadakan pemadaman listrik, pasti semua aktivitas kita sangatlah terganggu. Untuk mengurangi ketergantungan listrik dari PLN, perlu dicari sumber energi lain sebagai sumber listrik alternatif. Sumber energi alternatif yang sudah tetapi baru sedikit dikembangkan adalah energi angin, anergi ombak dan energi matahari. Sumber energi listrik alternatif lain yang sudah dikembangkan juga ada berasal dari limbah atau sampah. ${ }^{1}$ Arang adalah limbah residu dari proses penguraian panas terhadap bahan mengandung karbon yang sebagian besar komponennya adalah karbon. Proses penguraian panas ini dapat dilakukan dengan jalan memanasi bahan langsung atau tidak langsung di dalam timbunan, kiln atau tanur. Pada umumnya pemanfaatan arang dari kayu lebih unggul dibandingkan dengan pembakaran biomassa mentah karena selain tanpa asap dan emisi yang berlebihan juga karena nilai kalor (pembakaran) yang lebih tinggi. Di Indonesia, produksi arang secara umum memiliki keunggulan diantaranya bahan baku tersedia dalam jumlah yang cukup banyak dan dapat diambil dari berbagai dimensi dan jenis kayu seperti dari limbah industri, potongan kayu berdiameter kecil dan dari jenis kayu tidak komersial. ${ }^{2}$ Produksi arang selain dapat mengurangi jumlah limbah kayu juga meningkatkan nilai ekonomis kayu. Bahan baku 
arang juga dapat diperoleh dari limbah aktivitas kehutanan, pertanian, dan perkebunan sehingga pemanfaatan limbah sebagai bahan baku arang tidak hanya dari kayu tetapi juga non kayu. Limbah selain kayu dapat berbentuk bahan buangan yang tidak terpakai dan bahan sisa dari hasil pengolahan. Bahan-bahan ini dapat diolah lebih lanjut menjadi hasil samping yang berguna yaitu menjadi produk arang ataupun briket arang melalui pendekatan teknologi limbah.

Energi dari suatu benda adalah ukuran dari kesanggupan benda tersebut untuk melakukan suatu. Satuan energi adalah joule. Energi terbagi dalam berbagai macam/jenis, contohnya energi panas, energi air, energi batu bara, energi minyak bumi, energi listrik, energi matahari, energi angin, energi nuklir, dan energi bumi. Energi yang disebutkan di atas termasuk energi yang tidak dapat di perbaharui. Artinya, energi terebut sumbernya terbatas dan sulit di perbanyak. Penggunaan energi secara tidak terbatas akan mempercepat habisnya sumber energi sehingga saat ini pemerintah gencar melakukan kampanye hemat energi. Kebutuhan manusia yang tidak terbatas selalu di batasi dengan ketersediaan sumber daya untuk memenuhinya. Energi yang paling banyak digunakan untuk aktivitas manusia adalah energi minyak bumi dan energi listrik. Energi minyak bumi yang banyak digunakan dalam bahan kehidupan sehari-hari adalah minyak tanah, bensin, dan solar. Kenaikan harga minyak bumi menjadi masalah bagi pemerintah karena akan menambah biaya subsidi pemerintah. $^{3}$ Berdasarkan permasalahan tersebut dilakukan penelitian dengan judul "Pembuatan Elektroda Berbahan Air Rendaman Arang”.

Masalah yang akan dikaji dalam penelitian ini adalah Bagaimana pengaruh air rendaman arang untuk menghasilkan sumber energi alternatif yang ramah lingkungan. Berapa waktu rendam yang optimum untuk menghasilkan sumber energi alternatif ramah lingkungan.

Penelitian ini memiliki tujuan umum untuk mengetahui apakah air rendaman arang dapat menghasilkan sumber energi alternatif yang ramah lingkungan. Serta mengetahui lama waktu optimum rendam untuk menghasilkan sumber energi alternatif ramah lingkungan.

\section{Metodologi Penelitian}

Penelitian ini menggunakan rancangan penelitian eksperimen untuk mencari jenis air arang dengan tambahan seng dan tembaga serta mengukur tegangan sampel air arang untuk menentukan massa optimum dan waktu interaksi optimum. Penelitian dilakukan di rumah tempat tinggal peneliti yakni di dusun tanjung marulak,sungai kanan,labuhan batu selatan,sumatera utara.Variasi yang di pakai pada penelitian ini dari ukuran seng dan tembaga dengan air pam, air sumur.

\subsection{Alat dan Bahan}

Alat

1. Multimeter analog

2. Gelas plastik bekas

3. Tembaga ukuran $1 \times 5$ (sebanyak 8 buah) $2 \times 5 \mathrm{~cm}$ (sebanyak 8 buah) dan $3 \times 5 \mathrm{~cm}$ (sebanyak 8 buah)

4. Seng ukuran $1 \times 5$ (sebanyak 8 buah) $2 \times 5$ $\mathrm{cm}$ (sebanyak 8 buah) dan $3 \times 5 \mathrm{~cm}$ (sebanyak 8 buah)

5. Gunting

6. Wadah untuk rendaman arang

7. Plastik

8. Penggaris

9. Kabel tembaga

Bahan

1. Arang sebanyak 150 gram

2. Air pam 5 liter

3. Air sumur 5liter

2.2 Prosedur kerja

Tahap pertama yang dilakukan yaitu menyiapkan seluruh alat dan bahan yang diperlukan.kemudian masukkan arang kedalam plastik besar dan haluskan dengan cara digiling sampai benar benar halus.disiapkan air jenis pam dan sumur dengan masing masing tiga wadah.pada wadah diberi label dengan wadah pertama dengan air pam dimasukkan tembaga dan seng dengan ukuran 1x5 cm,diwadah kedua air pam dimasukkan tembaga dan seng dengan ukuran $2 \times 5 \mathrm{~cm}$,dan diwadah ketia air pam dimasukkan tembaga dan seng $3 \times 5 \mathrm{~cm}$.selanjutnya diwadah air sumur juga dilakukan dengan penambahan tembaga dan seng dengan variasi ukuran $1 \times 5,2 \times 5$, dan $3 \times 5 \mathrm{~cm}$.

Pada tahap selanjutnya,kedalam masing masing wadah air pam dan sumur dengan variasi ukuran tembaga dan seng dimasukkan arang yang telah dihaluskan sebanyak 25 gram setiap wadah,kemudian setiap wadah ditutup dengan plastik dan karet gelang dan direndam selama 24 jam. 
Setelah 24 jam dilakukan pengukuran tegangan listrik dengan multimeter analog dan kabel tembaga. Pengumpulan data diperoleh dengan eksperimen Uji tegangan listrik dari air rendaman arang (air sumur dan pam) dalam wadah dengan berbagai ukuran elektroda seng dan tembaga.

\section{Hasil dan Pembahasaan}

3.1 Hasil

Uji Tegangan Listrik

Air rendaman arang dengan air pam dan sumur dengan tambahan tembaga dan seng dengan variasi ukuran dan dengan waktu perendaman 24 jam.berikut tegangan listrik setiap wadah sesuai dengan tabel dibawah.

Tabel 1 Nilai tegangan perbedaaan air pam, air sumur dengan seng dan tembaga ukuran $1 \times 5 \mathrm{~cm}$.

\begin{tabular}{|l|l|l|}
\hline No & $\begin{array}{l}\text { Rendaman arang } \\
\text { dengan air pam }\end{array}$ & $\begin{array}{l}\text { Rendaman arang } \\
\text { dengan air sumur }\end{array}$ \\
\hline \multicolumn{3}{|c|}{ Tegangan listrik setiap wadah } \\
\hline 1 & $0,55 \mathrm{~V}$ & $0,55 \mathrm{~V}$ \\
\hline 2 & $0,55 \mathrm{~V}$ & $0,55 \mathrm{~V}$ \\
\hline 3 & $0,60 \mathrm{~V}$ & $0,65 \mathrm{~V}$ \\
\hline 4 & $0,80 \mathrm{~V}$ & $0,70 \mathrm{~V}$ \\
\hline 5 & $0,70 \mathrm{~V}$ & $0,70 \mathrm{~V}$ \\
\hline 6 & $0,55 \mathrm{~V}$ & $0,60 \mathrm{~V}$ \\
\hline 7 & $0,55 \mathrm{~V}$ & $0,60 \mathrm{~V}$ \\
\hline 8 & $0,60 \mathrm{~V}$ & $0,55 \mathrm{~V}$ \\
\hline 9 & $0,50 \mathrm{~V}$ & $0,70 \mathrm{~V}$ \\
\hline 10 & $0,50 \mathrm{~V}$ & $0,60 \mathrm{~V}$ \\
\hline
\end{tabular}

Tabel 2. Nilai tegangan perbedaaan air pam, air sumur dengan seng dan tembaga ukuran $2 \times 5 \mathrm{~cm}$.

\begin{tabular}{|l|l|l|}
\hline No & $\begin{array}{l}\text { Rendaman arang } \\
\text { dengan air pam }\end{array}$ & $\begin{array}{l}\text { Rendaman arang } \\
\text { dengan air sumur }\end{array}$ \\
\hline \multicolumn{3}{|c|}{ Tegangan listrik setiap wadah } \\
\hline 1 & $0,65 \mathrm{~V}$ & $0,60 \mathrm{~V}$ \\
\hline 2 & O,65 V & $0,60 \mathrm{~V}$ \\
\hline 3 & $0,70 \mathrm{~V}$ & $0,55 \mathrm{~V}$ \\
\hline 4 & $0,70 \mathrm{~V}$ & $0,55 \mathrm{~V}$ \\
\hline 5 & $0,60 \mathrm{~V}$ & $0,55 \mathrm{~V}$ \\
\hline 6 & $0,60 \mathrm{~V}$ & $0,55 \mathrm{~V}$ \\
\hline 7 & $0,60 \mathrm{~V}$ & $0,55 \mathrm{~V}$ \\
\hline 8 & $0,60 \mathrm{~V}$ & $0,55 \mathrm{~V}$ \\
\hline 9 & $0,75 \mathrm{~V}$ & $0,55 \mathrm{~V}$ \\
\hline 10 & $0,75 \mathrm{~V}$ & $0,55 \mathrm{~V}$ \\
\hline
\end{tabular}

Tabel 3. Nilai tegangan perbedaaan air pam, air sumur dengan seng dan tembaga ukuran $3 \times 5 \mathrm{~cm}$.

\begin{tabular}{|l|l|l|}
\hline No & $\begin{array}{l}\text { Rendaman arang } \\
\text { dengan air pam }\end{array}$ & $\begin{array}{l}\text { Rendaman arang } \\
\text { dengan air sumur }\end{array}$ \\
\hline \multicolumn{3}{|c|}{ Tegangan listrik setiap wadah } \\
\hline 1 & $0,70 \mathrm{~V}$ & $0,55 \mathrm{~V}$ \\
\hline 2 & O,70 V & $0,55 \mathrm{~V}$ \\
\hline 3 & $0,70 \mathrm{~V}$ & $0,60 \mathrm{~V}$ \\
\hline 4 & $0,70 \mathrm{~V}$ & $0,60 \mathrm{~V}$ \\
\hline 5 & $0,70 \mathrm{~V}$ & $0,60 \mathrm{~V}$ \\
\hline 6 & $0,70 \mathrm{~V}$ & $0,60 \mathrm{~V}$ \\
\hline 7 & $0,75 \mathrm{~V}$ & $0,55 \mathrm{~V}$ \\
\hline 8 & $0,75 \mathrm{~V}$ & $0,55 \mathrm{~V}$ \\
\hline 9 & $0,65 \mathrm{~V}$ & $0,60 \mathrm{~V}$ \\
\hline 10 & $0,65 \mathrm{~V}$ & $0,60 \mathrm{~V}$ \\
\hline
\end{tabular}

\subsection{Pembahasan}

Pembahasan Pada percobaan ini peneliti melakukannya setelah 24 jam perendaman untuk mengendapkannya dan bisa menghasilkan tegangan listrik. Data pada tabel 1, 2, 3 tegangan listrik penggunaan air dan penambahan variasi ukuran seng, tembaga sangat berpengaruh terhadap tegangan listrik yang dihasilkan. Hal ini disebabkan air sumur dan air pam bahwa air sumur mengandung konsentrasi ion Fluorida lebih tinggi ${ }^{4}$ berpengaruh terdahap tegangan yang pada umum diperoleh mengalami. a. Adanya penambahan ini menggunakan kombinasi dari seng, tembaga berbentuk pelat sebagai elektroda anoda dan katoda). ${ }^{5}$

Berdasarkan data eksperimen (Tabel 4.1) terlihat bawah tegangan listrik yang di peroleh dari air pam dan sumur sampel 2,3,4 mengalami kenaikan. Hal tersebut sesuai dengan konsentrasi ion fluorida dan tambahan kombinasi dari seng, tembaga namun juga ada yang mengalami penurunan dari sampel 5,6,7. Hal ini bisa disebabkan karena letak dari kedua sumur tersebut, dimana sumur dengan kadar kalsium tertinggi berada lebih jauh dari pantai (300meter dari pantai) sedangkan sumur dengan kadar kalsium lebih rendah terletak 50 meter dari pantai. Berdasarkan penelitian yang dilakukan terhadap kualitas air sumur berdasarkan parameter fisika, didapatkan kesimpulan bahwa semakin dekat jarak sumur dari tepi pantai maka kualitas airnya tidak baik, 
sebaliknya semakin jauh jarak sumur dari tepi pantai maka kualitas airnya baik. ${ }^{6,7}$

Berdasarkan data eksperimen (Tabel 2) terlihat bahwa tegangan listrik yang diperoleh dari air pam dan sumur bahwa yang air sumur mengalami penurunan. Hal tersebut sesuai bahwa air sumur, pada umumnya mengandung besi (iron, $\mathrm{Fe}$ ) dan mangan (manganese, Mn). Kandungan besi dan mangan dalam air berasal dari tanah yang memang mengandung banyak kandungan mineral dan logam yang larut dalam air tanah. Besi larut dalam air dalam bentuk ferooksida. Dengan adanya hal tersebut sangat berpengaruh terhadap seng, tembaga untuk menghasilkan tegangan listrik.

Berdasarkan data eksperimen (Tabel 3) terlihat bahwa tegangan listrik yang diperoleh dari air pam dan sumur bahwa yang air sumur mengalami penurunan dengan massa dan ukuran seng, tembaga pada sampel 5\&6, 7\&. Air tanah sering mengandung zat besi (Fe) dan Mangan (Mn) cukup besar. Adanya kandungan $\mathrm{Fe}$ dan $\mathrm{Mn} \hat{\mathrm{A}}$ menyebabkan warna air berubah berewarna kuning-coklat setelah beberapa saat kontak dengan udara. Berdasarkan hal tersebut tembaga dan seng mengalami pengaratan saat di rendamkan kedalam air sumur pada pengambilan data.

\section{Kesimpulan}

Berdasarkan pada uraian. Air rendaman arang dapat menjadi sumber energi listrik. Air rendaman arang akan memiliki tegangan yang besar apabila gelas-gelas ditambahkan dengan tembaga dan seng maka menghasilkan energi listrik atau tegangan. Terdapat tiga nilai tegangan perbedaaan pada jenis air yang digunakan air pam air dengan tambahan seng dan tembaga ukuran 1x5 $\mathrm{cm}, 2 \times 5 \mathrm{~cm}, 3 \times 5 \mathrm{~cm}$ yang hasilnya terjadi naik turun di setiap data. Seperti pada nilai tegangan perbedaaan pada jenis air yang digunakan air pam air sumur bervolume air $100 \mathrm{ml}$ dengan tambahan seng dan tembaga ukuran $2 \times 5 \mathrm{~cm}$. Air pam yaitu dengan tegangan listrik $0,65 \mathrm{~V}, 0,70 \mathrm{~V}, 0,60 \mathrm{~V}$, $0,60 \mathrm{~V}, 0,75 \mathrm{~V}$ dan air sumur yaitu dengan tegangan listrik $0,60 \mathrm{~V}, 0,55 \mathrm{~V}, 0,55 \mathrm{~V}, 0,55 \mathrm{~V}$, 0,55 V. Kurang maksimal frekuensi yang dihasilkan dengan dua gelas yang tidak di jadikan rangkaian seri atau pararel.

\section{Referensi}

1. L. Utami \& Y. Fatisa. (2019, Jan). "Electricity production from peat water uses microbial fuel cells technology". Indonesian Journal of Chemical Science and Technology. 02(1), pp. 55-60

2. G. Pari., K. Sofyan., \& W.B. Syafii. (2005). "Pengaruh Lama Aktivasi Terhadap Struktur Kimia Dan Mutu Arang Aktif Serbuk Gergaji Sengon". Jurnal Penelitian Hasil Hutan. 23(3), pp. 207-218.

3. L.O Muhammad., W. Abdul. (2005). Sensitivitas Analisis Potensi Produksi Pembangkit Listrik Renewable untuk Penyediaan Listrik Indonesia. 13-22

4. D. Soni., Prasetiawati., \& D.N. Sari. (2019, Jan). "Pengaruh Lokasi Terhadap Kadar Ion Fluorida Pada Air Sumur Dan Air Pam Dengan Metode Kolorimetri”. Jurnal Ilmiah Farmako Bahari. 10 (1), pp. 76-90

5. N. Akbar., M.R. Kirom., \& R.F. Iskandar. (2017). "Analisis Pengaruh Material Logam Sebagai Elektroda Microbial Fuel Cell Terhadap Produksi Energi Listrik". EProceeding of Engineering. 4(2), pp, 2132-2135

6. L. Fadillah., Jasmidi., R. Selly., \& M. Zubir. (2021, Jan). "Water purification process uses adsorbents from natural material". Indonesian Journal of Chemical Science and Technology. 04(1), pp. 42-44.

7. R.A.F. Lubis., H.I. Nasution., \& M. Zubir. (2020, July). "Production of activated carbon from natural sources for water purification". ndonesian Journal of Chemical Science and Technology. 03(2), pp. 67-73 